\title{
Identification of predictive biomarkers of peri- and postpartum disorders in dairy cows
}

\author{
Jae-Kwan Jeong', Tai-Young Hur ${ }^{2}$, Young-Hun Jung ${ }^{3}$, Hyun-Gu Kang ${ }^{1}$, Ill-Hwa Kim ${ }^{1, *}$ \\ ${ }^{1}$ College of Veterinary Medicine, Chungbuk National University, Cheongju 28644, Korea \\ ${ }^{2}$ Dairy Science Division, National Institute of Animal Science, Cheonan 31000, Korea \\ ${ }^{3}$ Division of Animal Disease and Health, National Institute of Animal Science, Rural Development Administration, \\ Wanju 55365, Korea
}

\begin{abstract}
We aimed to identify predictive markers of peri- and postpartum disorders in dairy cows. Data regarding peri- and postpartum disorders, serum metabolites, body condition score (BCS), and rectal temperature, were collected from 227 dairy cows, which were allocated to healthy $(\mathrm{n}=57)$ and diseased $(\mathrm{n}=170)$ groups. Serum non-esterified fatty acid (NEFA) concentration was higher in diseased than healthy cows 4 weeks before $(p<0.01)$ and immediately after $(p=0.05)$ calving. Serum alanine aminotransferase (AST) activity was higher $(p<0.05)$ in diseased than healthy cows 1 and 2 weeks after calving, whereas total cholesterol (TCH) concentration was lower $(p<0.05-0.0001)$ in diseased cows 4 weeks before, and after calving. BCS was higher $(p<0.05)$ in diseased than healthy cows 4 weeks before calving, but lower $(p<0.01)$ in diseased cows 8 weeks after calving. Rectal temperature was higher $(p<0.05-0.01)$ in diseased than healthy cows between 2 and 14 days postpartum. In conclusion, high serum NEFA and AST concentrations and lower TCH concentration during the peripartum period, and high prepartum BCS and postpartum rectal temperature, could be used as biomarkers to predict the subsequent development of peri- and postpartum disorders.
\end{abstract}

Keywords: biomarkers, body condition score, dairy cow, metabolite, rectal temperature

\section{*Corresponding author}

Ill-Hwa Kim

College of Veterinary Medicine, Chungbuk National University, 1 Chungdae-ro,

Seowon-gu, Cheongju 28644, Korea

Tel: $+82-43-261-2571$

Fax: $+82-43-267-3150$

E-mail: illhwa@cbu.ac.kr

ORCID:

Jae-Kwan Jeong

https://orcid.org/0000-0002-8379-3194

Tai-Young Hur

https://orcid.org/0000-0003-3129-2942

Young-Hun Jung

https://orcid.org/0000-0002-8094-0304

Hyun-Gu Kang

https://orcid.org/0000-0002-3827-6112

Ill-Hwa Kim

https://orcid.org/0000-0002-2092-0264

Conflict of Interest

The authors declare no conflicts of interest.

Received: November 18, 2018

Revised : December 8, 2018

Accepted: January 8, 2019

\section{Introduction}

Dairy cows experience metabolic imbalance due to the severe burden of having to meet their energy requirements for the production of colostrum and lactation during the peri- and postpartum periods [1]. This high energy requirement results in negative energy balance (NEB), which begins a few days before calving and peaks approximately 2 weeks later [2, 3]. During the period, significant metabolic and immunological changes occur in dairy cows, which predispose towards peri- and postpartum metabolic and infectious diseases $[4,5]$, such as milk fever, ketosis, retained placenta, metritis, and abomasal displacement $[6,7]$. Moreover, the higher milk yield of modern dairy herds exacerbates the NEB, increasing the incidence of peri- and postpartum disorders, which are associated with a reduction in milk production and poorer reproductive outcomes [8]. Thus, these health problems during transition are associated with impairments in animal welfare and economic loss to dairy producers, especially in high-yielding herds.

The concentrations of several blood metabolites change, and thus reflect the metabolic conditions, during transition in dairy cows, especially around calving and during the early postpartum period. Thus, numerous studies of the relationships between metabolite concentrations, particularly non-esterified fatty acids (NEFAs) and $\beta$-hydroxybutyrate (BHBA), and the incidence of postpartum disorders, such as ketosis, abomasal displacement, retained placenta, and metritis, have been undertaken [9-11]. The data obtained have established the use of NEFA and BHBA as predictors of postpartum metabolic and reproductive disorders. However, further investigation of the relationships between a variety of blood metabolites and peripartum health problems is required to identify and validate additional biomarkers that could be used to improve the health of dairy herds. 
The assessment of body condition is a simple and useful method of evaluating body energy reserves and nutritional status in dairy cows [12]. It changes during the lactation period, especially around calving and during early lactation, and a marked change at this time may reflect severe energy imbalance, which is associated with a greater risk of pre- and postpartum disorders developing and impaired reproductive performance [13-15]. For this reason, the frequent assessment of body condition could be used as a predictor of animal health, especially of the development of metabolic disorders or subsequent reproductive outcomes [16].

Body temperature monitoring is a commonly used method of detecting the presence of disease in dairy herds, especially in postpartum dairy cows [17]. Furthermore, the measurement of rectal temperature for 5-10 days after calving has been incorporated into standard operating protocols for fresh cow health management and has been used to determine when further investigations of potential disease are required [18]. Thresholds of $39.4^{\circ} \mathrm{C}$ and $39.7^{\circ} \mathrm{C}$ have been used to distinguish between healthy cows and cows with infectious disease $[17,19,20]$, because several diseases, in particular metritis, mastitis, and pneumonia, have been shown to cause increases in body temperature [21, 22]. However, repeated measurement of rectal temperature might be necessary to diagnose infectious diseases in postpartum dairy cows.

Although intensive farming, characterized by low calving index and high milk yield, has dramatically improved the productivity of dairy herds in recent years in Korea, the incidence of peri- and postpartum disorders has markedly increased [23]. Because these health problems result in poorer productivity and reproduction in dairy herds [24], especially in high-yielding herds, the identification of biomarkers that could predict peri- and postpartum disorders during transition is required to help reduce the incidence of these disorders. Such biomarkers could be used in the dairy industry by both veterinary practitioners and producers.

High-yielding dairy cows are also prone to multiple diseases after calving. Thus, the quantification of a panel of biomarkers, including blood metabolites, body condition score (BCS), and rectal temperature during the transition period could be valuable for the prediction of peri- or postpartum health problems. Moreover, such a panel could become a useful component of a health monitoring system for dairy herds. Therefore, the objective of this study was to identify biomarkers that could predict the development of peri- and postpartum disorders. To this end, several serum metabolites, BCS, and rectal temperature were evaluated in dairy cows during this phase of their productive cycle.

\section{Materials and Methods}

\section{Animals}

This study was conducted on 4 dairy farms in Chungcheong Province, each with a herd consisting of $\sim 90-200$ cows. The cows were maintained in loose housing systems, fed total mixed rations, and milked twice daily. The mean milk yields for the farms were $\sim 9,500-12,000 \mathrm{~kg}$ per cow per year.

Two hundred and twenty-seven cows (65 primiparous and 162 multiparous; parity, mean \pm SD $2.4 \pm 1.4$ ) were included in the study. All cows underwent weekly reproductive health checks by veterinarians on the research team, including an examination of their ovarian structures (follicle and corpus luteum) and uterus by transrectal palpation and ultrasonography.

\section{Study design}

On the basis of the presence or absence of peri- or postpartum disorders, the 227 cows were determined to be healthy $(n=57)$ or diseased $(n=170)$. The peri- or postpartum disorders recorded in the present study were dystocia $(n=46)$, retained placenta $(n=68)$, ketosis $(n=42)$, milk fever $(n=13)$, abomasal displacement $(n=9)$, digestive disorders $(n=12)$, puerperal metritis $(n=81)$, clinical endometritis $(n=95)$, mastitis $(n=22)$, and lameness $(n=20)$.

Serum concentrations of metabolites (NEFA, BHBA, glucose, albumin, total protein, urea nitrogen, alanine aminotransferase $[\mathrm{AST}], \gamma$-glutamyltransferase $[\gamma \mathrm{GT}]$, total cholesterol $[\mathrm{TCH}]$ ), calcium, magnesium, and phosphorus) and BCS were compared between the healthy and diseased cows 4 weeks before calving, immediately after calving, and at 1,2 , 4,6 , and 8 weeks postpartum. In addition, rectal temperature was measured daily between the 1 st and 14th day in milk (DIM) and compared between the 2 groups.

\section{Clinical definitions}

The definitions of each peri- and postpartum disorder used in the present study were similar to those described previously $[22,25,26]$. Dystocia was defined as calving requiring some or significant force, or cesarean section. Retained placenta was defined as the retention of the fetal membranes for longer than $24 \mathrm{~h}$. Ketosis was diagnosed in the presence of a combination of anorexia, depression, and the odor of acetone on the breath. Milk fever was diagnosed by weakness and recumbence after calving. Abomasal displacement was diagnosed by a "ping" sound during abdominal auscultation by a veterinarian. Digestive disorders included diarrhea and bloat. Puerperal metritis was defined by the presence of fever $\left(\geq 39.5^{\circ} \mathrm{C}\right)$ and a watery, fetid uterine discharge during the first 10 days after calving. Clinical endometritis was diagnosed on the basis of the presence of a visible mucopurulent vaginal discharge and/or rectal palpation and ultrasonography 4 weeks after calving. Mastitis was recorded if abnormal milk or signs of inflammation in 1 or more quarters of the udder were present. Lameness was diagnosed if an abnormal gait or lack of weight-bearing on a limb was observed, and included diagnoses of interdigital and digital dermatitis. The presence of postpartum disorders was recorded up to 4 weeks after calving, except in the case of particular disor- 
ders, for which the timing of diagnosis is given above. With the exception of dystocia and mastitis, postpartum disorders were diagnosed by veterinarians in the research team.

\section{Blood sampling, and measurement of BCS and rectal temperature}

Blood samples were collected from the tail vein 4 weeks before calving, immediately after calving $(0.5-3 \mathrm{~h})$ and at 1 , $2,4,6$, and 8 weeks postpartum, to determine serum concentrations of NEFA, BHBA, glucose, albumin, total protein, urea nitrogen, AST, $\gamma \mathrm{GT}, \mathrm{TCH}$, calcium, magnesium, and phosphorus. Ten milliliters of blood were placed into plastic centrifuge tubes without additives and immediately placed in an ice bath. The samples were then centrifuged at 2,000 $\times \mathrm{g}$ for $10 \mathrm{~min}$ at $4^{\circ} \mathrm{C}$, and the serum was harvested and frozen at $-80^{\circ} \mathrm{C}$ until assayed.

At the same time as the blood collection, BCS was evaluated on a 5-point scale, with quarter-point divisions, using the visual technique developed by Edmonson et al. [12]. Rectal temperature was measured daily between the 1st and 14th DIM using a digital thermometer (FORA MT-4218; Eujin Med Electronic, Korea), between $0700 \mathrm{~h}$ and $0900 \mathrm{~h}$.

\section{Quantification of serum metabolites}

The concentrations of NEFA, BHBA, glucose, albumin, total protein, urea nitrogen, AST, $\gamma \mathrm{GT}$, TCH, calcium, magnesium, and phosphorus in serum samples were measured using a 7180 Biochemistry Automatic Analyzer 710 (Hitachi, Japan) and commercial enzyme assay kits (Wako Pure Chemical, Japan), according to the manufacturer's instructions. The intra- and inter-assay coefficients of variation were $<5 \%$ for each assay.

\section{Statistical analyses}

Data are expressed as the mean \pm SEM. For statistical analysis, cows were categorized as either primiparous or multiparous. Statistical analyses were performed using the SAS program (ver. 9.4; SAS Institute, USA).

All data (concentrations of serum metabolites, BCS, and rectal temperature) were analyzed using mixed models. The statistical models for the concentrations of serum metabolites and BCS included group (diseased cows or healthy controls), sampling or measurement time (4 weeks before calving, immediately after calving, or at $1,2,4,6$, or 8 weeks postpartum), and 2-way interactions between group, cow parity, and sampling or measurement time.

For rectal temperature, the statistical model included group, measurement time (between the 1st and 14th DIM), and 2-way interactions between group, cow parity, and measurement time. Student's $t$-test was performed when a group effect was observed.

The $p \leq 0.05$ was considered to represent statistical significance and $0.05<p \leq 0.1$ was considered to indicate a trend nearing significance.

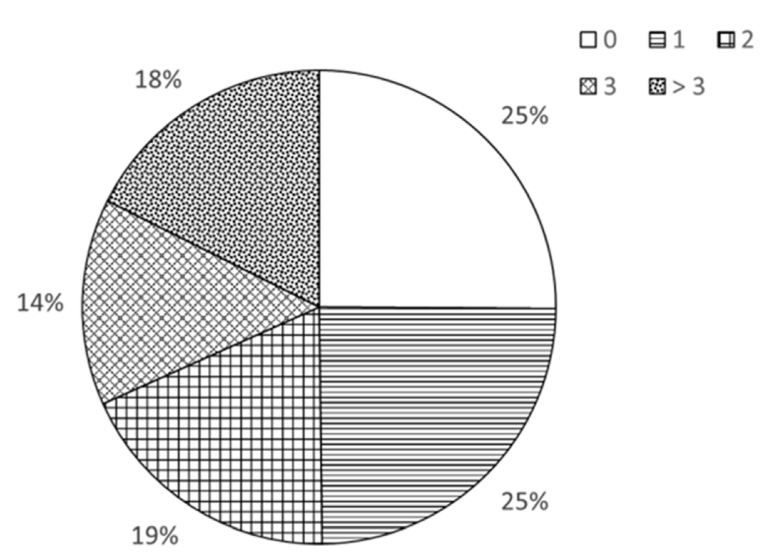

Fig. 1. Percentages of 227 Holstein dairy cows with peri- or postpartum disorders. 0 , healthy cows $(57 / 227)$; 1 , cows with a single disorder $(56 / 227) ; 2$, cows with 2 disorders (42/227); 3 , cows with 3 disorders $(32 / 227)$; $>3$, cows with 4 or more disorders (40/227).

\section{Results}

Frequency of peri- and postpartum disorders

Healthy cows constituted $25.1 \%$ (57/227) of the sample and the remainder $(74.9 \%, 170 / 227)$ had 1 or more disorders (Fig. 1): 1 disorder, 24.7\% (56/227); 2, 18.5\% (42/227); 3, $14.1 \%$ (32/227); and 4 or more, $17.6 \%$ (40/227).

Relationships between serum concentrations of metabolites and peri- and postpartum disorders

Figure 2 shows a comparison of the serum concentrations of metabolites between healthy and diseased cows 4 weeks before calving, immediately after calving, and 1, 2, 4, 6, and 8 weeks after calving. Serum NEFA was higher in diseased than healthy cows 4 weeks before calving $(p<0.01)$ and immediately after calving ( $p=0.05$, Fig. $2 \mathrm{~A})$, whereas glucose concentration tended to be lower $(p=0.1)$ in diseased than healthy cows 8 weeks postpartum (Fig. 2B). AST concentration was higher $(p<0.05)$ in diseased than healthy cows 1 and 2 weeks after calving, whereas it was lower in diseased cows 6 and 8 weeks after calving $(p<0.05-0.01$, Fig. 2C). Serum TCH concentrations were lower in diseased cows than healthy cows 4 weeks before calving $(p<0.05)$, and $1,2,4,6$, and 8 weeks after calving $(p<0.01-0.0001$, Fig. 2D). However, BHBA, albumin, total protein, urea nitrogen, $\gamma \mathrm{GT}$, calcium, magnesium, and phosphorus concentrations did not differ between the healthy and diseased cows $(p$ $>0.1$ ).

\section{Relationships between BCS and peri- and postpartum} disorders

Figure 3 shows a comparison of BCS between healthy and diseased cows 4 weeks before calving, immediately after calving, and 1, 2, 4, 6, and 8 weeks after calving. There were no significant effects of group $(p>0.1)$, but there were significant effects of measurement time $(p<0.0001)$ and an 

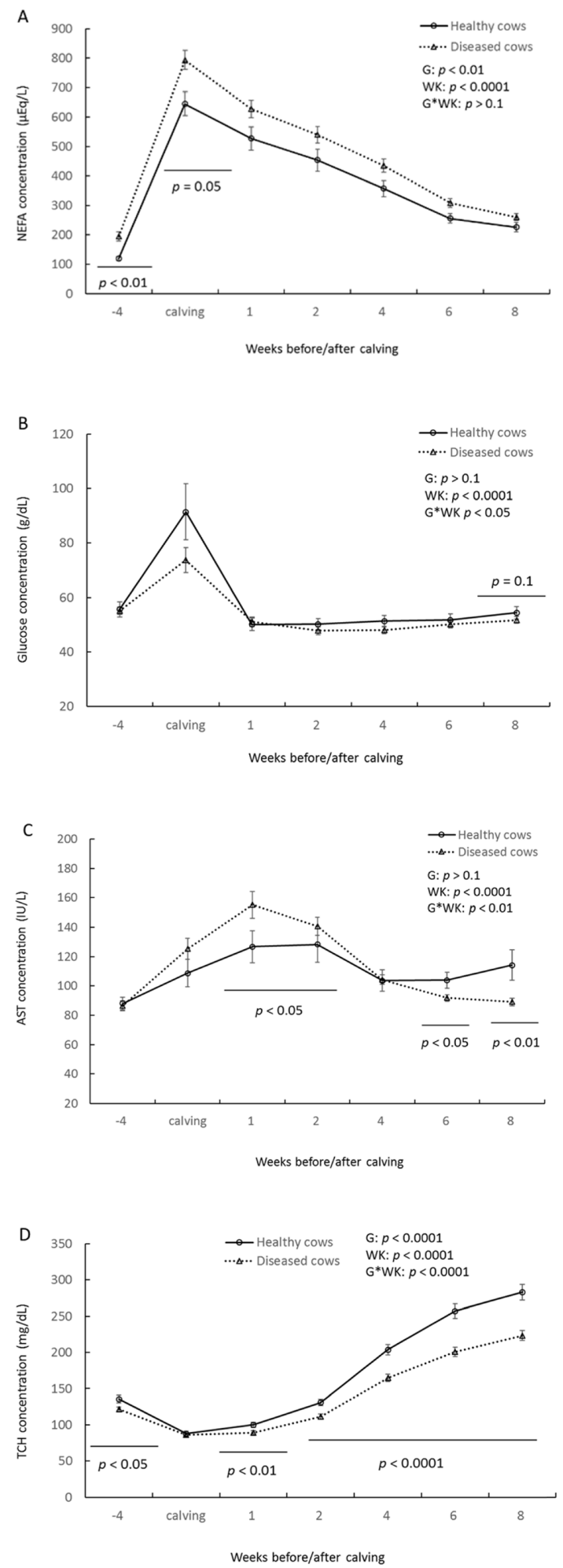

Fig. 2. Comparison of serum NEFA (A), glucose (B), AST (C), and TCH (D) concentrations between healthy $(n=57)$ and diseased $(n=170)$ cows 4 weeks before calving, immediately after calving, and $1,2,4,6$, and 8 weeks after calving. G, group effect; WK, sampling time effect; $\mathrm{G}^{*} \mathrm{WK}$, group-by-sampling time effect; NEFA, non-esterified fatty acid; AST, alanine aminotransferase; TCH, total cholesterol.

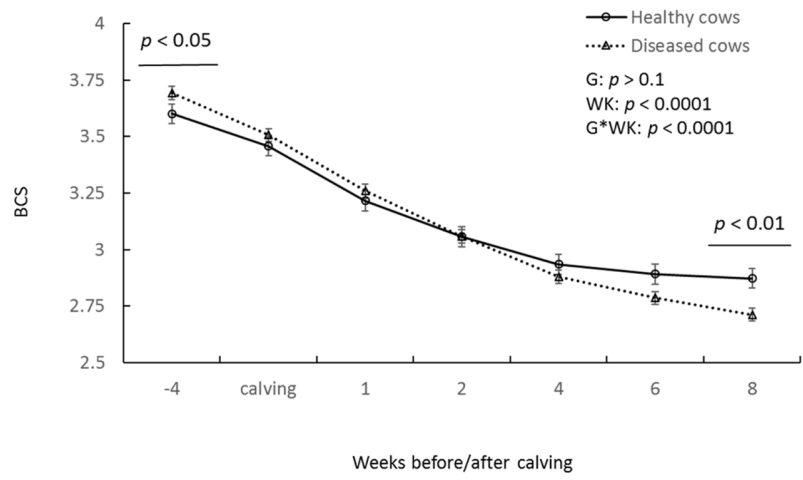

Fig. 3. Comparison of BCS between healthy and diseased cows 4 weeks before calving, immediately after calving, and 1,2, 4, 6 , and 8 weeks after calving. There were no significant effects of group $(p>0.1)$, but there were significant effects of measurement time $(p<0.0001)$ and an interaction between group and measurement time $(p<0.0001)$. BCS was higher $(p<0.05)$ 4 weeks before calving in diseased than healthy cows, but lower $(p<0.01) 8$ weeks after calving in diseased than healthy cows. BCS, body condition score; G, group effect; WK, measuring time effect; $G^{*} W K$, group-by-measuring time effect.

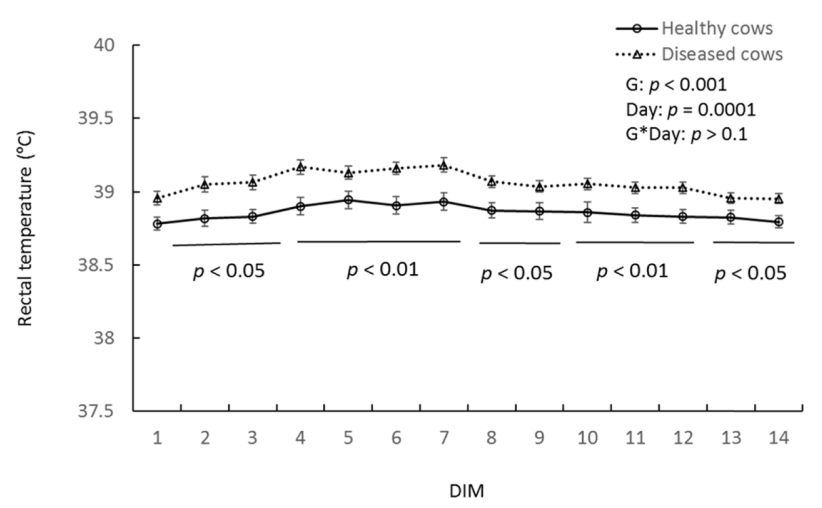

Fig. 4. Comparison of rectal temperature in healthy and diseased cows between the 1st and 14th DIM. There were significant effects of group $(p<0.001)$ and measurement time $(p=0.0001)$, but there was no interaction between group and measurement time $(p>0.1)$. Rectal temperature was higher $(p<0.05-0.01)$ in diseased than healthy cows between the 2nd and 14th DIM. G, group effect; Day, measuring time effect; G*Day, group-by-measuring time effect; DIM, day in milk.

interaction between group and measurement time $(p<0.0001)$. BCS was higher $(p<0.05)$ in diseased than healthy cows 4 weeks before calving, whereas BCS was lower $(p<0.05-$ 0.01 ) in diseased than healthy cows 7 and 8 weeks after calving.

Relationships between rectal temperature and periand postpartum disorders

Figure 4 shows a comparison of rectal temperature between healthy and diseased cows between the 1st and 14th DIM. There were significant effects of group $(p<0.001)$ and measurement time $(p=0.0001)$, but there was no interaction 
between these variables $(p>0.1)$ with respect to rectal temperature. Rectal temperature was higher $(p<0.05-0.01)$ in diseased than healthy cows between the 2nd and 14th DIM.

\section{Discussion}

This study aimed to identify biomarkers that could be used to predict the onset of peri- or postpartum disorders by evaluating serum metabolite concentrations, BCS, and rectal temperature in periparturient dairy cows. Our data show that higher serum NEFA and AST concentrations and lower TCH concentration, together with higher prepartum BCS and postpartum rectal temperature, are associated with a greater risk of peri- and postpartum disorders in dairy cows. These biomarkers could therefore be used to predict the development of peri- and postpartum disorders in dairy herds, and could be implemented as part of a peri- and postpartum health monitoring program.

The percentage of cows without signs of any disorders was quite low $(25.1 \%)$, and that of cows with multiple disorders was high $(50.2 \%)$ in the present study. A previous study that was undertaken in a commercial dairy operation in New York State categorized $42 \%$ of cows as healthy and $58 \%$ as having at least 1 adverse health event, of which $70 \%$ had only 1 event and 30\% had more than 1 [27]. Although the reasons for the substantial differences in the overall incidence of disorders and the percentages of cows with multiple disorders between studies are not clear, they might be related to differences in the characteristics of the animals, their nutritional and/or health management, the environment (climate and regional geography), the disorders considered, or the use of differing diagnostic tools. Of these potential explanations, insufficient nutritional or health management for the milk yield expected might be particularly important. Another study involved $37.5 \%$ of cows manifesting at least 1 health problem and $59.0 \%$ having at least 1 subclinical health problem, while only $27 \%$ of the sample were not diagnosed with either a clinical or subclinical disease problem in the postpartum period [24]. Thus, a similar percentage of healthy cows were identified in this and the present study.

To identify biomarkers that could predict the development of peri- or postpartum disorders, we evaluated the relationships between serum concentrations of NEFA, BHBA, glucose (representing energy status), albumin, total protein, urea nitrogen (representing protein status), AST, $\gamma \mathrm{GT}$, TCH (representing liver function), and calcium, magnesium, and phosphorus (representing mineral status), and the incidence of specific peri- and postpartum disorders. Previous studies have shown that the periparturient serum concentrations of NEFA and BHBA could be used to predict the risk of certain postpartum diseases developing [6, 9]. However, we found that serum NEFA was higher in diseased than healthy cows in the peripartum period, whereas BHBA concentrations did not differ between diseased and healthy cows throughout the study period. Our findings regarding the asso- ciation of high NEFA concentrations with the incidence of postpartum disorders are consistent with those of previous studies [9, 10]. However, these studies showed that high BHBA concentrations were also associated with postpartum disorders, such as abomasal displacement, clinical ketosis, metritis, and retained placenta. In addition, another study showed that cows with retained placenta, metritis, mastitis, ketosis, or laminitis had higher prepartum NEFA concentrations than healthy cows, and cows with retained placentas had higher prepartum BHBA concentrations than healthy cows [14]. Furthermore, a study by Giuliodori et al. [28] conducted in Argentina showed that high prepartum NEFA and postpartum BHBA concentrations were associated with a higher risk of clinical endometritis. Finally, Cheong et al. [29] found that multiparous cows with ketosis were 5.6 times more likely to have subclinical endometritis and suggested that this is likely the result of impaired uterine immune function due to NEB. Indeed, high NEFA and BHBA concentrations, reflecting severe NEB, might be associated with more severe immune system suppression, manifesting in impaired neutrophil function, during the periparturient period [30].

Our finding that BHBA concentrations did not differ between diseased and healthy cows might be due to differences in the identity of the disorders included in the metabolite data analyses. In our study, we included almost all of the disorders that tend to occur during the peri- and postpartum periods, whereas other studies generally only considered metabolic disorders. Interestingly, however, 1 study found that several immune cell (peripheral blood mononuclear cell) functions appear to be associated with NEFA concentration, and NEFAs have been shown to have a negative effect on the oxidative burst, while BHBA has not [31]. The findings of the present and other studies suggest that the identification of a high NEFA concentration during the peripartum period could be used to predict the development of a single metabolic disorder or multiple disorders including a metabolic disorder during the pre- or postpartum periods. However, our finding that serum glucose concentration tended to be lower in diseased than healthy cows only from 8 weeks after calving indicates that glucose concentration is not associated with the incidence of peri- and postpartum disorders, but rather that it might reflect the sequelae of such disorders.

A prolonged period during which the liver receives a high concentration of NEFA tends to result in an impairment of the liver function, associated with incomplete oxidization of the NEFA. Thus, dairy cows experience impaired liver function, coupled with more severe inflammation and oxidative stress during the peripartum period [32, 33]. This poor liver function can be associated with various postpartum health problems, including abomasal displacement, ketosis, mastitis, and metritis [34]. Thus, serum AST, $\gamma \mathrm{GT}, \mathrm{TCH}$, or bilirubin concentrations are commonly used to assess periparturient liver function [34, 35]. In the present study, the identification of high AST (a positive acute phase protein) and low TCH (a negative acute phase protein) concentrations in diseased 
cows during the transition period suggests that they have impaired liver function, which may well contribute to the development of peri- and postpartum disorders. Consistent with our results, AST concentrations were higher between 2 and 13 weeks postpartum in cows that developed clinical mastitis than in healthy cows [36]. Another study also showed that TCH concentrations are lower in cows with retained placenta, metritis, mastitis, ketosis, or laminitis than in healthy cows between 1 and 7 weeks after calving [14]. Taking all these findings together, the measurement of serum metabolites, and in particular the identification of high NEFA and low $\mathrm{TCH}$ concentrations during the peripartum period and a high AST concentration during the first or second week postpartum, could be useful for the prediction of peri- and postpartum disorders in dairy herds. However, further research will be necessary to explain why the concentrations of indicators of protein status (albumin, total protein, and urea nitrogen) and mineral status (calcium, magnesium, and phosphorus) did not differ between healthy and diseased cows.

$\mathrm{BCS}$ is an indirect measure of energy balance that can be useful for the prediction of subsequent animal health, productivity, and reproductive status [15]. Fatter cows mobilize more body reserves and reduce dry matter intake during early lactation [34]. In the present study, BCS was higher 4 weeks before calving in diseased than healthy cows, but lower in diseased than healthy cows 8 weeks after calving. Our data show that high BCS towards end of the dry period is unfavorable for peri- and postpartum health, as also demonstrated in other studies [37, 38]. Higher prepartum BCS might also contribute to the high periparturient serum NEFA concentration identified in diseased cows in the present study. Conversely, lower BCS 8 weeks after calving might also be responsible for the lower glucose concentration at the same time point in diseased cows, because it implies poor energy status. However, a previous study showed that prepartum BCS did not differ between diseased and healthy cows [14].

Daily measurement of rectal temperature during the early postpartum period makes the early identification of postpartum complications possible in dairy cows [17]. Therefore, we compared the rectal temperature of diseased and healthy cows between the $1 \mathrm{st}$ and 14 th DIM, and found that it was higher in diseased $\left(39.1 \pm 0.04^{\circ} \mathrm{C}\right)$ than healthy $\left(38.9 \pm 0.05^{\circ} \mathrm{C}\right)$ cows between the 2nd and 14th DIM. The normal body temperature of cattle has been reported to be $38.6^{\circ} \mathrm{C}[19,39]$, which was a similar to our finding. Moreover, a previous study showed that rectal temperature is higher in cows with an infectious disease (mastitis, metritis, or pneumonia, with or without a concurrent metabolic health event) $\left(39.1^{\circ} \mathrm{C}\right)$ than in cows without such a condition $\left(38.7^{\circ} \mathrm{C}\right)$ between the $1 \mathrm{st}$ and 10th DIM [40]. However, the authors showed that rectal temperature did not differ between cows with metabolic disease (milk fever, digestive upset, retained placenta, abomasal displacement, or diarrhea) $\left(38.8^{\circ} \mathrm{C}\right)$ and healthy cows during the same period [40]. Another study showed that the mean rectal temperature of cows with puerperal metritis and fever $\left(39.2^{\circ} \mathrm{C}\right)$ was higher than that of those without calving-related problems $\left(38.6^{\circ} \mathrm{C}\right)$ between the 3rd and 13th DIM [19], which is consistent with our results. It has also been suggested that a rectal temperature threshold of $39.5^{\circ} \mathrm{C}$ should be used for the diagnosis of puerperal metritis [22]. Taken together, these findings suggest that daily measurement of rectal temperature between the 2nd and 10th or 14th DIM would be beneficial for the earlier diagnosis of postpartum disorders of an infectious origin in dairy cows.

In summary, the present study has identified biomarkers that could be used for the prediction of subsequent peri- and postpartum disorders during the transition period in dairy cows. Our results show that high serum NEFA and low TCH concentrations during the peripartum period and a high AST concentration during the first or second week postpartum could be useful predictors of peri- or postpartum disorders, whether single or multiple. In addition, demonstration of a high BCS 4 weeks before calving (towards end of the dry period) and a high rectal temperature between the 2nd and 14th DIM could also be predictive of peri- or postpartum disorders in dairy herds. We believe that these biomarkers could be included as part of a peri- and postpartum health monitoring program.

\section{Acknowledgment}

This work was supported by the Cooperative Research Program for Agriculture Science and Technology Development (project no. PJ01191503), Rural Development Administration, Korea.

\section{References}

1. Baird GD. Primary ketosis in the high-producing dairy cow: clinical and subclinical disorders, treatment, prevention, and outlook. J Dairy Sci 1982;65:1-10.

2. Bell AW. Regulation of organic nutrient metabolism during transition from late pregnancy to early lactation. J Anim Sci 1995;73:2804-2819.

3. Butler WR, Smith RD. Interrelationships between energy balance and postpartum reproductive function in dairy cattle. J Dairy Sci 1989;72:767-783.

4. Ingvartsen KL. Feeding- and management-related diseases in the transition cow: physiological adaptations around calving and strategies to reduce feeding-related diseases. Anim Feed Sci Technol 2006;126:175-213.

5. LeBlanc S. Monitoring metabolic health of dairy cattle in the transition period. J Reprod Dev 2010;56 Suppl:S29-S35.

6. Chapinal N, Carson M, Duffield TF, Capel M, Godden S, Overton M, Santos JE, LeBlanc SJ. The association of serum metabolites with clinical disease during the transition period. J Dairy Sci 2011;94:4897-4903.

7. Rukkwamsuk T, Kruip TA, Wensing T. Relationship between overfeeding and overconditioning in the dry period and the problems of high producing dairy cows during the postparturient period. Vet Q 1999;21:71-77.

8. Ingvartsen KL, Dewhurst RJ, Friggens NC. On the 
relationship between lactational performance and health: is it yield or metabolic imbalance that cause production diseases in dairy cattle? A position paper. Livest Prod Sci 2003;83: 277-308.

9. Ospina PA, Nydam DV, Stokol T, Overton TR. Evaluation of nonesterified fatty acids and $\beta$-hydroxybutyrate in transition dairy cattle in the northeastern United States: critical thresholds for prediction of clinical diseases. J Dairy Sci 2010;93:546-554.

10. Seifi HA, Leblanc SJ, Leslie KE, Duffield TF. Metabolic predictors of post-partum disease and culling risk in dairy cattle. Vet J 2011;188:216-220.

11. Suthar VS, Canelas-Raposo J, Deniz A, Heuwieser W. Prevalence of subclinical ketosis and relationships with postpartum diseases in European dairy cows. J Dairy Sci 2013;96:2925-2938.

12. Edmonson AJ, Lean IJ, Weaver LD, Farver T, Webster G. A body condition scoring chart for Holstein dairy cows. J Dairy Sci 1989;72:68-78.

13. Berry DP, Lee JM, Macdonald KA, Stafford K, Matthews L, Roche JR. Associations among body condition score, body weight, somatic cell count, and clinical mastitis in seasonally calving dairy cattle. J Dairy Sci 2007;90:637-648.

14. Qu Y, Fadden AN, Traber MG, Bobe G. Potential risk indicators of retained placenta and other diseases in multiparous cows. J Dairy Sci 2014;97:4151-4165.

15. Roche JR, Friggens NC, Kay JK, Fisher MW, Stafford KJ, Berry DP. Invited review: body condition score and its association with dairy cow productivity, health, and welfare. J Dairy Sci 2009;92:5769-5801.

16. Roche JR, Macdonald KA, Schütz KE, Matthews LR, Verkerk GA, Meier S, Loor JJ, Rogers AR, McGowan J, Morgan SR, Taukiri S, Webster JR. Calving body condition score affects indicators of health in grazing dairy cows. J Dairy Sci 2013;96:5811-5825.

17. Smith BI, Risco CA. Management of periparturient disorders in dairy cattle. Vet Clin North Am Food Anim Pract 2005; 21:503-521.

18. Kristula M, Smith BI, Simeone A. The use of daily postpartum rectal temperatures to select dairy cows for treatment with systemic antibiotics. Bov Pract (Stillwater) 2001;35:117-125.

19. Benzaquen ME, Risco CA, Archbald LF, Melendez P, Thatcher MJ, Thatcher WW. Rectal temperature, calving-related factors, and the incidence of puerperal metritis in postpartum dairy cows. J Dairy Sci 2007;90:2804-2814.

20. Wagner SA, Schimeck DE, Cheng FC. Body temperature and white blood cell count in postpartum dairy cows. Bov Pract (Stillwater) 2007;42:18-26.

21. Adams AE, Olea-Popelka FJ, Roman-Muniz IN. Using temperature-sensing reticular boluses to aid in the detection of production diseases in dairy cows. J Dairy Sci 2013;96: 1549-1555.

22. Sheldon IM, Lewis GS, LeBlanc S, Gilbert RO. Defining postpartum uterine disease in cattle. Theriogenology 2006; 65:1516-1530.

23. Jeong JK, Choi IS, Kang HG, Jung YH, Hur TY, Kim IH. Postpartum reproductive tract recovery and prevalence of health problems in dairy cows. J Vet Clin 2015;32:168-173.

24. Ribeiro ES, Lima FS, Greco LF, Bisinotto RS, Monteiro AP,
Favoreto M, Ayres H, Marsola RS, Martinez N, Thatcher WW, Santos JE. Prevalence of periparturient diseases and effects on fertility of seasonally calving grazing dairy cows supplemented with concentrates. J Dairy Sci 2013;96:56825697.

25. Loeffler SH, de Vries MJ, Schukken YH. The effects of time of disease occurrence, milk yield, and body condition on fertility of dairy cows. J Dairy Sci 1999;82:2589-2604.

26. Lombard JE, Garry FB, Tomlinson SM, Garber LP. Impacts of dystocia on health and survival of dairy calves. J Dairy Sci 2007;90:1751-1760.

27. Stangaferro ML, Wijma R, Caixeta LS, Al-Abri MA, Giordano JO. Use of rumination and activity monitoring for the identification of dairy cows with health disorders: part I. Metabolic and digestive disorders. J Dairy Sci 2016;99:73957410 .

28. Giuliodori MJ, Magnasco RP, Becu-Villalobos D, LacauMengido IM, Risco CA, de la Sota RL. Clinical endometritis in an Argentinean herd of dairy cows: risk factors and reproductive efficiency. J Dairy Sci 2013;96:210-218.

29. Cheong SH, Nydam DV, Galvão KN, Crosier BM, Gilbert RO. Cow-level and herd-level risk factors for subclinical endometritis in lactating Holstein cows. J Dairy Sci 2011; 94:762-770.

30. Hammon DS, Evjen IM, Dhiman TR, Goff JP, Walters JL. Neutrophil function and energy status in Holstein cows with uterine health disorders. Vet Immunol Immunopathol 2006; 113:21-29.

31. Ster C, Loiselle MC, Lacasse P. Effect of postcalving serum nonesterified fatty acids concentration on the functionality of bovine immune cells. J Dairy Sci 2012;95:708-717.

32. Bionaz M, Trevisi E, Calamari L, Librandi F, Ferrari A, Bertoni G. Plasma paraoxonase, health, inflammatory conditions, and liver function in transition dairy cows. J Dairy Sci 2007;90:1740-1750.

33. Trevisi E, Amadori M, Cogrossi S, Razzuoli E, Bertoni G. Metabolic stress and inflammatory response in high-yielding, periparturient dairy cows. Res Vet Sci 2012;93:695-704.

34. Bobe G, Young JW, Beitz DC. Invited review: pathology, etiology, prevention, and treatment of fatty liver in dairy cows. J Dairy Sci 2004;87:3105-3124.

35. Bertoni G, Trevisi E, Han X, Bionaz M. Effects of inflammatory conditions on liver activity in puerperium period and consequences for performance in dairy cows. J Dairy Sci 2008;91:3300-3310.

36. Moyes KM, Larsen T, Friggens NC, Drackley JK, Ingvartsen KL. Identification of potential markers in blood for the development of subclinical and clinical mastitis in dairy cattle at parturition and during early lactation. J Dairy Sci 2009;92:5419-5428.

37. Drackley JK, Cardoso FC. Prepartum and postpartum nutritional management to optimize fertility in high-yielding dairy cows in confined TMR systems. Animal 2014;8 Suppl 1:5-14.

38. Roche JR, Meier S, Heiser A, Mitchell MD, Walker CG, Crookenden MA, Riboni MV, Loor JJ, Kay JK. Effects of precalving body condition score and prepartum feeding level on production, reproduction, and health parameters in pasture-based transition dairy cows. J Dairy Sci 2015;98: 7164-7182. 
8 Jae-Kwan Jeong, Tai-Young Hur, Young-Hun Jung, Hyun-Gu Kang, Ill-Hwa Kim

39. Andersson BE, Jónasson H. Temperature regulation and environmental physiology. In: Dukes $\mathrm{HH}$, Swenson MJ, Reece WO (eds.). Dukes' Physiology of Domestic Animals. 11th ed. pp. 886-895, Cornell University Press, Ithaca, 1993.
40. Wenz JR, Moore DA, Kasimanickam R. Factors associated with the rectal temperature of Holstein dairy cows during the first 10 days in milk. J Dairy Sci 2011;94:1864-1872. 